\section{The Other Side of Medicine}

The issues dealt with not only pertain to MSF as a humanitarian organisation, but also touch on an important and often neglected aspect of medicine in general. Political figures are most influential, but spend most of their time in the public spotlight and little time in direct contact with the actual subjects of their lavish speeches; activist groups are most devoted, and actively promote their cause, but often lack credibility and professional experience. The medical personnel is by far the best placed people to raise the issues of justice, dignity and human rights, not only because of their well-respected social status but also because of their direct contact with victims. The importance of activism in medicine is perhaps not so obvious in Canada, where the majority of population not only has access to medical care but is also protected under strict laws. But it becomes very obvious when working in countries where there is little protection of human rights and little or no medical assistance available, and where health emergencies are often the result of violence, oppression and injustice.

I have often heard medicine being referred to as a "noble" profession. There is nothing noble to be found in the medical field if treating a patient is viewed as merely operating on a machine. If practicing medicine does not go beyond fulfilling the job requirements and earning a good salary, it is no more noble than any other profession. There is a tendency to immediately classify a career in medicine as an admirable one because of the prospect of saving many lives. There is a distinction to be made however, between those who do it with apathy, out of duty or as a routine, and those who truly care for the relief of human suffering, who believe in the high ideals of medical ethics, who are in quest of knowledge and understanding without prejudice, who sacrifice and labour and endure to help others, who are outraged by the sight of any form of abuse of another human being and who take action against it. Therein lies true nobility.

Sincerely,

Sophie Zhang

Faculty of Science

McGill University

\section{REFERENCES}

1. MSF Canada. The Work of MSF: Past, Present, and Future. Medicins Sans Frontières / Doctors Without Borders, Canada. www.msf.ca/about. 2003.

2. Parry MS. Phyrric Victories and the Collapse of Humanitarian Principles. The Journal of Humanitarian Assistance. www.jha.ac/articles/a094.htm. 2002.

3. Macrae J, Stevenson F. Legislating for Humanitarian Aid. Humanitarian Practice Network Report. 2002; 21: 33-35.
4. Center for Economic \& Social Rights. Violations of the Right to Food by all Parties to the Conflict in Afghanistan. www.cesr.org/Emergency\%20Response/righttofoodrapportuer.d oc. 2001.

5. Ignatieff M. The Stories We Tell: Television and Humanitarian Aid. In: Moore, ed. Hard Choices: Moral Dilemmas in Humanitarian Intervention. Lanham, Maryland: Rowman \& Littlefield. 1998: 291.

6. De Waal A. The End of the Cold War: A New Humanitarian Dispensation, In: Currey, ed. Famine Crimes: Politics and the Disaster Relief Industry in Africa. Bloomington, Indiana: Indiana University Press; 1997: 65.

7. Bouchet-Saulnier F. Between Humanitarian Law and Principles: The Principles and Practices of "Rebellious Humanitarianism." Medicins Sans Frontières / Doctors Without Borders, Canada. www.msf.org/content/page.cfm?articleid=6589C8A5-DC2C11D4-B2010060084A6370. 2000.

8. MSF France, Chronologie de 1971 à aujourd'hui. www.paris.msf.org/msf/web.nsf/html/459PGX?OpenDocument. 2001.

9. Marschner A. A Scientific Approach to "Témoignage." Medicins Sans Frontières / Doctors Without Borders, Canada. www.msf.org/content/page.cfm?articleid=0F722DE2-BF6A11D4-852200902789187E. 1999.

10 Melicharova M. Special Agents. Peace Matters. 2002; 38: 23.

\section{FOURTEENTH EUROPEAN STUDENTS CONFERENCE}

\section{Dear MJM,}

Given, that the MJM and the European Students' Conference (ESC) share the common goal of encouraging the pursuit and communication of medical research among students, we thought your readers might be interested in learning more about our Conference.

As our name implies, the Conference enjoys a European flavor but we wish to actively encourage Northern American students to also attend, facilitating closer ties and a greater flux of ideas between the two continents.

The 14th European Students Conference will be held from the 4th - 9th of November 2003, at Charité, the medical school of the Humboldt University in Berlin. It offers medical students and young doctors from more than 40 countries a great opportunity to present the findings of their research. Uniquely, professors and specialists will evaluate them. Prices and scholarships totalling more than 10.000 Euro will be awarded to the best oral and poster presentations.

The fields of Neuro Science, Pharmacology and Infectious Diseases are our main focal points at the 14th ESC and we welcome everybody working or researching in this field. Besides that different 
workshops concerning topics in medical education, fundraising for medical projects, working in Europe or alternative medicine will be offered. In addition there will be a forum for interactive discussions between highly regarded scientists and students. Combining with the conference sessions there will be initial skill adaption training courses as chances to get in touch with the practical side of medicine. We will also have an exhibition - the "job contact market", where subject related companies can present themselves or recruit young scientists directly.

One of the main goals of the 14th ESC is anchored in our leitmotif, which expresses our interdisciplinary thinking: For open minded young scientists willing to look beyond.

Our wide variety of cultural and social programme points implies the aim to show Berlin as a European capital with its specific flair and a doorway between east and west. Historical oriented sightseeing tours as well as dinner parties and sport activities will be part of the programme to bring people together.

The 14th ESC has recently extended the agreement with the IFMSA (International Federation of Medical Students' Associations, ifmsa.org) during the March meeting in Estonia. The IFMSA's Standing Committee on Research Exchange (SCoRE) recommends that the participants of its research exchange attend at the 14th European Students' Conference and present their work. If you have done a research and you are going to attend an exchange programme, why not apply the 14th ESC? We enthusiastically welcome students and young doctors from the biomedical sector worldwide to become active as well as passive applicants. The application details and further information are noted down in writing on our website:

esc.charite.de

www.esc-berlin.com

Yours faithfully,

The Organizing Committee

N. Züfle, N. Ledenig, W. Blaum, A. Schuster, A. Gómez-Carrillo, A. Kötter, F. Ufer, S. Herrmann

\section{A MEETING OF THE MINDS}

\section{Dear $M J M$,}

On February 26, 2003, the Experimental Medicine Graduate Students' Society (EMGSS) proudly hosted the 3rd Annual McGill Biomedical Graduate Conference (AMBGC) at McGill University. The AMBGC was created to strengthen relations among graduate students and to promote awareness of the research being performed throughout the university. The AMBGC gives graduate students the opportunity to hone their presentation skills and to get feedback on their research from a diverse audience.

The 3rd AMBGC attracted over 250 people and a record high of 102 abstracts were submitted by graduate students from 14 biomedical departments, representing 15 different research institutes. This year's keynote lecture was given by Dr. Lawrence Rosenberg of McGill. Dr. Rosenberg's lecture focused on the discovery of INGAP, a naturally-derived peptide which stimulates the regeneration of pancreatic islet cells and is being touted as a potential cure for diabetes. Unfortunately, due to a personal emergency, Dr. Rosenberg's co-speaker, Dr. Aaron I. Vinik of Eastern Virginia Medical School, could not attend.

Overall, the 2003 AMBGC provided an outstanding forum for biomedical graduate students to share some of the exciting research currently being performed at McGill. The EMGSS would like to thank all of the sponsors, graduate students and judges who participated in this event. For more information and for pictures from the 3rd AMBGC, please visit the conference website (1).

Sincerely,

Randy Levitt and Sabrina Perri

Co-Presidents, Experimental Medicine Graduate Students' Society (EMGSS)

McGill University

\section{REFERENCES}

1. EMGSS. 3rd Annual McGill Biomedical Graduate Conference.

http://www .medcor.mcgill.ca/EXPMED/AMBGC 